\title{
Anti-inflammatory and Immunosuppressive Effects of Panax notoginseng
}

\author{
Thao Quyen Cao ${ }^{\dagger}$, Jae Hyuk Han ${ }^{\dagger}$, Hyun-Su Lee, Manh Tuan Ha, Mi Hee Woo, and Byung Sun Min* \\ College of Pharmacy, Drug Research and Development Center, Daegu Catholic University, Gyeongbuk 38430 , \\ Republic of Korea
}

\begin{abstract}
Here, we designed to examine the anti-inflammatory effects on RAW264.7 cells and the immunosuppressive effects by evaluating interleukin-2 (IL-2) production in Jurkat T cells using a MeOH extract of Panax notoginseng roots. The results showed that the $\mathrm{MeOH}$ extract inhibited the synthesis of nitric oxide (NO) in a dose-dependent manner $\left(\mathrm{IC}_{50}\right.$ value of $\left.7.08 \mu \mathrm{g} / \mathrm{mL}\right)$ and displayed effects on $\mathrm{T}$ cell activation at a concentration of $400 \mu \mathrm{g} / \mathrm{mL}$. In efforts to identify the potent compounds, bioactivity-guided fractionation of the $\mathrm{MeOH}$ extract and chemical investigation of its active $\mathrm{CH}_{2} \mathrm{Cl}_{2^{-}}$, EtOAc-, and butanol- soluble fractions led to the successful isolation and identification of eleven compounds, including two polyacetylenes (1, 2), a steroid saponin (3), seven dammarane-type ginsenosides (4-10), and an oleanane-type ginsenoside (11). Among them, compound $\mathbf{1 1}$ was isolated from this plant for the first time. Compound $\mathbf{2}$ exhibited potent inhibitory effects on $\mathrm{NO}$ synthesis and an immunosuppressive effect with $\mathrm{IC}_{50}$ values of 2.28 and $65.57 \mu \mathrm{M}$, respectively.

Keywords - Panax notoginseng, anti-inflammation, immunosuppressive, ginsenoside, polyacetylene, saponin
\end{abstract}

\section{Introduction}

The immune system is a complex system responsible for protecting us against infections and foreign substances. The immune system can generally be classified into two different arms, the innate and adaptive immune systems. The innate immune system responds quickly but nonspecifically. In contrast, the adaptive immune system has specificity (T cell receptor, B cell receptor) and a memory capacity against infections. This enables it to protect the host during a primary infection and provides a stronger and better-adapted response following secondary infection with the same pathogen. ${ }^{1}$ The regulation of $\mathrm{T}$ cell activation is a potential strategy for the treatment of immune diseases, as well as for transplant rejection. T cells play an important role in immune responses because they can act as regulators and effectors of immune function. $\mathrm{T}$ cells have been demonstrated to be activated and dysfunctional in patients with immune diseases, such as systemic lupus erythematosus and rheumatoid arthritis. ${ }^{2}$ Interleukin-2 (IL-2) is a potent $\mathrm{T}$ cell growth factor and is produced

\footnotetext{
* Author for correspondence

Byung Sun Min, College of Pharmacy, Drug Research and Development Center, Daegu Catholic University, Gyeongbuk 38430, Republic of Korea.

Tel: +82-53-850-3613; Email: bsmin@cu.ac.kr
}

${ }^{\dagger}$ These authors contributed equally to this work primarily by activated $\mathrm{T}$ cells. Moreover, the development of T cells and the transcription of IL-2 are regulated by a series of intracellular signaling pathways, including the mitogen-activated protein kinase (MAPK) pathway. ${ }^{3}$ Furthermore, immune cells, including macrophages, release pro-inflammatory cytokines (e.g. TNF- $\alpha, \mathrm{IFN}-\gamma$ ) upon ligation of their pattern recognition receptors (PRRs) with pathogen-associated molecular patterns (PAMPs) present on bacterial surfaces or viral DNA/RNA. ${ }^{4}$ This process then leads to the release of other chemicals at the inflamed site. At the inflamed site, these newly-recruited immune cells secrete chemokines to recruit other immune cells to aid in the fight against infection and these series of events together form the inflammatory response. Inflammation is a physiological process meant to alert the immune system to the presence of pathogens, tissue injury, or other aggressions. ${ }^{5}$ Hence, inflammation is a necessary process that requires a tight regulation and the regulatory functions of the immune system are important in controlling infection and resolving inflammation.

Panax L. is a small genus of the family Araliaceae. Notoginseng is a remedy with a long history of use in China and other Asian countries. The botanical name for notoginseng is Panax notoginseng (Burk.) F.H. Chen. ${ }^{6,7} P$. notoginseng is known to be a rich source of saponins, amino acids, polysaccharides, and flavonoids. ${ }^{8}$ Furthermore, P. notoginseng has a number of very important activities, 
including antihypertensive, antithrombotic, anti-atherosclerotic, neuroprotective actions, anti-inflammatory, antioxidant, and anti-aging effects. ${ }^{9-11}$

In this study, to determine the bioactivities of $P$. notoginseng, we examined anti-inflammatory effects by evaluating NO production in RAW264.7 cells and immunosuppressive effects by evaluating IL-2 production in Jurkat $\mathrm{T}$ cells from the treatment with the $\mathrm{MeOH}$ extract of $P$. notoginseng roots. We found that the $\mathrm{MeOH}$ extract inhibited the synthesis of nitric oxide (NO) and IL-2 expression in dose-dependent manners. In our efforts to characterize compounds in the $\mathrm{MeOH}$ extract responsible for these anti-inflammatory and immunosuppressive effects, bioactivity-guided fractionation and chemical investigation of the $\mathrm{MeOH}$ extract were performed, which led to the successful isolation of two polyacetylenes (1, 2), a steroid saponin (3), seven dammarane-type ginsenosides (4-10), and an oleanane-type ginsenoside (11). Herein, we report the bioactivities of $P$. notoginseng roots and the identification of the isolated compounds responsible for the anti-inflammatory and immunosuppressive effects.

\section{Experimental}

General procedures-UV spectra were recorded using a Thermo spectrometer. IR spectra were recorded using a JASCO FT/IR-4100 spectrometer. 1D and 2D NMR spectra were obtained using Varian Unity Inova 400 $\mathrm{MHz}$ and $500 \mathrm{MHz}$ spectrometer with tetramethylsilane (TMS) as an internal standard, and the chemical shifts were recorded in $\delta$ values (ppm). Mass spectra were recorded using a JEOLJMS-AX 300L spectrometer. Silica gel (Merck, 63 - $200 \mu \mathrm{m}$ particle size) and RP-18 (Merck, $75 \mu \mathrm{m}$ particle size) were used for column chromatography. TLC was performed using Merck silica gel 60 $\mathrm{F}_{254}$ and RP-18 $\mathrm{F}_{254}$ plates. Preparative HPLC was performed using a Gilson Trilution system with an UV detector (UV/VIS-156) and an YMC-Pack ODS-A column $(250 \times 20 \mathrm{~nm}, 5 \mu \mathrm{m}$ particle size, YMC Co. Ltd, Japan). HPLC solvents were purchased from Burdick \& Jackson (USA).

Plant material-The roots of $P$. notoginseng were purchased in December 2015, from a traditional medicine store, named as "Bon-Cho-Won", in Jeollabuk-do, Korea, and identified by Professor Byung-Sun Min, Daegu Catholic University, Korea. A voucher specimen (CUD3182) is deposited at the Herbarium of the College of Pharmacy, Daegu Catholic University, Korea.

Extraction and isolation - The roots of $P$. notoginseng $(10.0 \mathrm{~kg})$ were extracted three times with methanol. The methanol solution was concentrated under reduced pressure to give a crude extract $(2.0 \mathrm{~kg})$. After that, the crude extract was suspended in hot water $(1.5 \mathrm{~L})$ and partitioned with $n$-hexane, $\mathrm{CH}_{2} \mathrm{Cl}_{2}$, EtOAc, $n$-butanol and water, successively, to afford $n$-hexane- $(10.09 \mathrm{~g}), \mathrm{CH}_{2} \mathrm{Cl}_{2}$ $(9.38 \mathrm{~g})$, EtOAc- $(23.98 \mathrm{~g}), n$-butanol- $(300.3 \mathrm{~g})$, and water- $(1.0 \mathrm{~kg})$ soluble fractions, respectively. By the bioactivity-guided fractionation, the $\mathrm{CH}_{2} \mathrm{Cl}_{2}$ extract $(9.38 \mathrm{~g}$ ) was subjected to a silica gel column using $n$-hexaneacetone $(9: 1 \rightarrow 0: 1)$ as eluents to acquire seven fractions (C1-C7). Fraction C1 (337.0 mg) was chromatographed over a silica gel column and eluted with $n$-hexane-EtOAc $(10: 1 \rightarrow 0: 1)$ to obtain compound 1 (24.9 mg). Compound $2(622.5 \mathrm{mg})$ was obtained by the subjection in a silica gel column and elution with $n$-hexane-EtOAc $(8: 1 \rightarrow 0: 1)$. Next, EtOAc extract (23.98 g) was subjected into a silica gel column using $\mathrm{CH}_{2} \mathrm{Cl}_{2}-\mathrm{MeOH}(6: 1 \rightarrow 0: 1)$ to afford ten fractions (E1-E10). Fraction E3 (1.7 g) was chromatographed over a silica gel column and eluted with $\mathrm{CH}_{2} \mathrm{Cl}_{2}-$ $\mathrm{MeOH}(6: 1)$ to obtain compound $3(10.3 \mathrm{mg})$ and collect three subfractions (E3.1-E3.3). Then, subfraction E3.3 (213.2 $\mathrm{mg}$ ) was subjected to a silica gel column using solvent system $\mathrm{CH}_{2} \mathrm{Cl}_{2}-\mathrm{MeOH}-\mathrm{H}_{2} \mathrm{O}(10: 2: 1 \rightarrow 0: 1: 0)$ to obtain compounds $6(14.3 \mathrm{mg})$ and $10(24.9 \mathrm{mg})$. Compound $4(2.469 \mathrm{~g})$ was obtained from fraction E5 $(4.0 \mathrm{~g})$ by the application to an $\mathrm{RP}^{-\mathrm{C}_{18}}$ silica gel column and elution using $\mathrm{MeOH}-\mathrm{H}_{2} \mathrm{O}(2: 1)$. Fraction E7 (2.5 g) was applied to an $\mathrm{RP}-\mathrm{C}_{18}$ silica gel column and eluted using $\mathrm{MeOH}-\mathrm{H}_{2} \mathrm{O}(3: 2)$ to afford three subfractions (E7.1E7.3). Subfraction E7.3 (489.1 mg) was chromatographed over a silica gel column and eluted with $\mathrm{CH}_{2} \mathrm{Cl}_{2}-\mathrm{MeOH}-$ $\mathrm{H}_{2} \mathrm{O}$ (7:3:1) to obtain compound 7 (98.3 mg). After that, fraction E10 $(901.8 \mathrm{mg})$ was subjected in a silica gel column and eluted with $\mathrm{CH}_{2} \mathrm{Cl}_{2}-\mathrm{MeOH}-\mathrm{H}_{2} \mathrm{O}$ (7:3:1) to obtain compound $5(10.8 \mathrm{mg})$. Afterwards, fraction E6 (10.2 g) was chromatographed over a silica gel column and eluted with $\mathrm{CH}_{2} \mathrm{Cl}_{2}-\mathrm{MeOH}-\mathrm{H}_{2} \mathrm{O}$ (6:3:1) to obtain compound 8 (119.2 mg). Fraction E9 (2.8 g) was subjected into an $\mathrm{RP}_{-} \mathrm{C}_{18}$ silica gel column and eluted using $\mathrm{MeOH}-$ $\mathrm{H}_{2} \mathrm{O}(2: 1)$ to obtain compound 9 (1.12 g) and collect six subfractions (E9.1-E9.6). Finally, compound 11 (34.6 $\mathrm{mg}$ ) was obtained from subfraction E9.3 $(80.1 \mathrm{mg})$ by HPLC [eluted with a gradient solvent system of $\mathrm{MeOH}-$ $\mathrm{H}_{2} \mathrm{O}(50: 50 \rightarrow 90: 10)$ over $60 \mathrm{~min}$; flow rate: $5 \mathrm{~mL} / \mathrm{min}$; UV detection at $210 \mathrm{~nm}$, and $254 \mathrm{~nm}$; an YMC-Pack ODS-A, $250 \times 20 \mathrm{~mm}$ column; $\left.\mathrm{t}_{\mathrm{R}}=30 \mathrm{~min}\right]$.

Cell culture - RAW264.7 cells, stocked in Dulbecco's Modified Essential, were grown at the condition of $37^{\circ} \mathrm{C}$ in DMEM supplemented with $10 \%$ heat-inactivated fetal bovine serum (FBS), streptomycin sulfate $(100 \mu \mathrm{g} / \mathrm{mL})$, 
and penicillin (100 units $/ \mathrm{mL})$ in a humidified atmosphere of $5 \% \mathrm{CO}_{2}$. RAW264.7 cells were pre-incubated for every two days. In addition, Jurkat T cells (ATCC CRL-1651, Manassas, VA, USA) were grown in RPMI medium (Gibco-BRL, Gaithersburg, MD, USA), supplemented with $10 \%$ heat-inactivated FBS, penicillin (100 units $/ \mathrm{mL})$, and streptomycin sulfate $(100 \mu \mathrm{g} / \mathrm{mL})$. Jurkat $\mathrm{T}$ cells were pre-incubated for every two days at $37^{\circ} \mathrm{C}$ in a humidified atmosphere of $5 \% \mathrm{CO}_{2}$.

Cell viability assay on RAW264.7 cells - The cytotoxic effect of the test samples on RAW264.7 cells was determined by a cell viability assay. RAW264.7 cells were seeded on a 96-wells plate at a density of $1 \times 10^{5}$ cells/ well and incubated $4 \mathrm{~h}$ for adhesion. After that, the cells were treated with $0.5 \%$ DMSO (control) or $\mathrm{MeOH}$ extract of $P$. notoginseng, its fractions, and isolated compounds at the indicated concentrations. Twenty four hours later, the viable cells were measured with a colorimetric assay based on the mitochondria ability in viable cells to reduce MTT. ${ }^{12}$ The viability cells were treated with vehicle only was defined as $100 \%$ viable. The formula was used to calculate the percentage of the macrophage survival cells after treatment is $\left[\mathrm{OD}_{570}\right.$ (treated cell culture) $\left.\times 100\right] /$ $\mathrm{OD}_{570}$ (vehicle control).

Measurement of nitric oxide (NO) production - We measured the amount of nitric from the cell culture supernatants to determine the level of NO production as described previously. In brief, the RAW264.7 cells were stimulated with or without $1 \mu \mathrm{g} / \mathrm{mL}$ of LPS, which was purchased from Sigma Chemical Co. (St. Louis, MO), for $24 \mathrm{~h}$ in with or without of $0.5 \%$ DMSO (control) or $\mathrm{MeOH}$ extract of $P$. notoginseng, its fractions, and isolated compounds at the indicated concentrations. Then, the cell culture supernatant $(100 \mu \mathrm{L})$ was reacted with $100 \mu \mathrm{L}$ of Griess reagent. ${ }^{12}$ After Griess assay, the remaining cells were used to screen for their viability using colorimetric assay-MTT (Sigma Chemical Co., St. Louis, MO), as previous described.

Reverse transcription PCR and PCR - Total RNA was isolated from Jurkat $\mathrm{T}$ cells using TRIZOL reagent (JBI, Korea). cDNA was synthesized by performing reverse transcription PCR using RT Pre-Mix (Enzymomics, Korea). The mRNA level of the IL-2 and GAPDH gene were measured by PCR with primers. The primers and PCR conditions for each gene were as follows: human IL2, 5'-CACGTCTTGCACTTGTCAC-3' and 5'-CCTTCTT GGGCATGTAAAACT-3'; human GAPDH, 5'-CGGAGT CAACGGATTTGGTCGTAT-3' and 5'-AGCCTTCTCCA TGGTGGTGAAGAC-3'. The amplification profile consisted of denaturation at $94{ }^{\circ} \mathrm{C}$ for $30 \mathrm{~s}$, annealing at $60{ }^{\circ} \mathrm{C}$ for $20 \mathrm{~s}$, and extension at $72{ }^{\circ} \mathrm{C}$ for $40 \mathrm{~s}$. The 30 cycles were preceded by denaturation at $72{ }^{\circ} \mathrm{C}$ for $7 \mathrm{~min}$.

Statistical analysis - The data were described as the mean \pm standard error of mean (SEM). Two-tailed unpaired student's t-test performed the statistical analyses and $\mathrm{p}<0.01$ was regarded statistically significant.

\section{Results and discussion}

The macrophage is an important antigen-presenting and effector cell in anti-tumor immunity. Activated macrophages mediate most of the cellular and molecular aspects of inflammation by producing cytokines and other proinflammatory molecules, including prostaglandins, enzymes, and free radicals (e.g. nitric oxide [NO]). ${ }^{13,14} \mathrm{NO}$, synthesized from L-arginine by three nitric oxide synthase (NOS) isoforms, is a signaling molecule that regulates various physiological and pathophysiological processes in the human body. iNOS, an isoform of the NOS family, can be induced by lipopolysaccharide (LPS) and various cytokines, including interleukin-1 (IL-1), interferongamma (IFN- $\gamma$ ), and tumor necrosis factor-alpha (TNF$\alpha) .{ }^{15}$ LPS-induced NO production by iNOS reflects the degree of inflammation within a given system. In RAW264.7 murine macrophages, LPS stimulation alone is known to induce iNOS transcription and protein synthesis and subsequent NO production. ${ }^{16}$ Hence, RAW264.7 cells and LPS are excellent models for evaluating potential inhibitors of the pathways that induce NO and iNOS production.

The dried roots of $P$. notoginseng were extracted with $\mathrm{MeOH}$ at $65^{\circ} \mathrm{C}$ and filtered. The filtrate was evaporated under reduced pressure with a rotavapor to obtain a crude extract, which was examined for anti-inflammatory properties using LPS-stimulated RAW264.7 cells. As shown in Fig. 1, the level of NO was significantly reduced in a dose-dependent manner after treatment with $\mathrm{MeOH}$ extract with an $\mathrm{IC}_{50}$ value of $7.08 \pm 0.11 \mu \mathrm{g} / \mathrm{mL}$ (Fig. 1A). A cell viability assay was conducted to analyze the cytotoxic effects of the extract. The $\mathrm{MeOH}$ extract exhibited cytotoxicity from the concentration of $50 \mu \mathrm{g} /$ $\mathrm{mL}$ (Fig. 1B). These results demonstrated that the $\mathrm{MeOH}$ extract of $P$. notoginseng exhibited anti-inflammatory effects and its chemical components could be investigated for their pharmacologic properties.

The $\mathrm{MeOH}$ extract was solvent-partitioned with $n$ hexane, $\mathrm{CH}_{2} \mathrm{Cl}_{2}, \mathrm{EtOAc}$, and $n$-butanol, yielding four main fractions, which were then filtered, concentrated, and freeze-dried. Varying concentrations of the main fractions were subsequently screened for inhibitory effects 

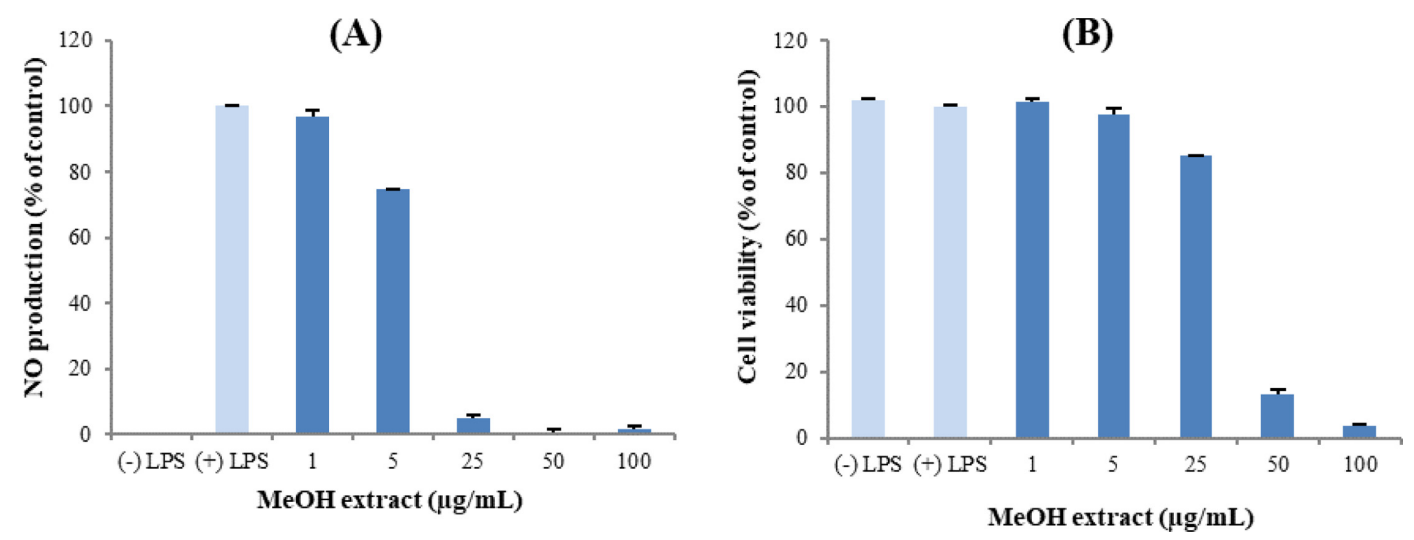

Fig. 1. Inhibitory effects of $P$. notoginseng $\mathrm{MeOH}$ extract on LPS-induced RAW264.7 cells. (A) The suppression of nitric oxide production by $\mathrm{MeOH}$ extract was determined by measurement accumulated nitrite in the culture medium through the Griess reaction. (B) The cytotoxic effect of MeOH extract on RAW264.7 cells was evaluated through a cell viability assay.
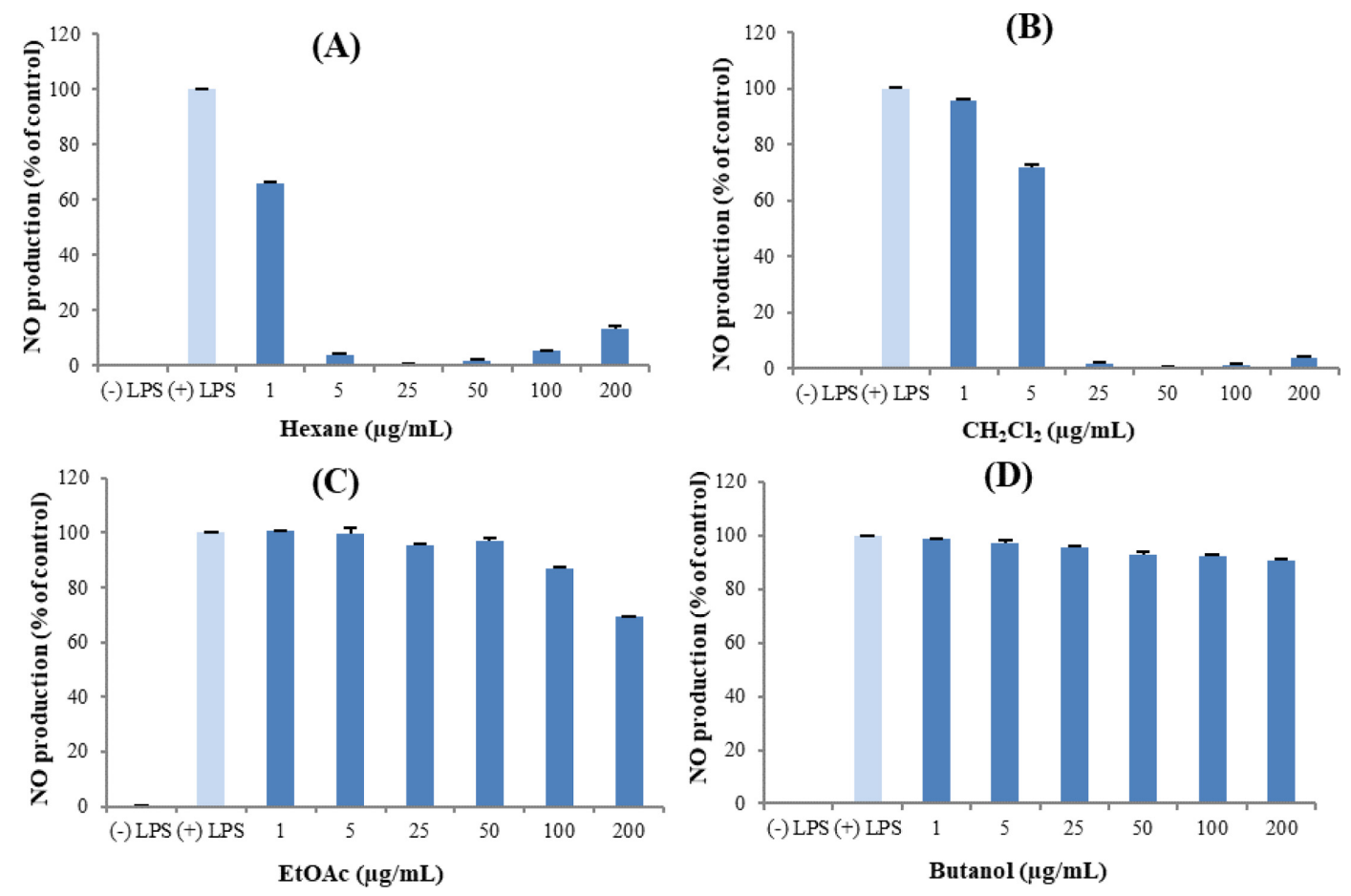

Fig. 2. The anti-inflammatory effects of the solvent-fractions from $P$. notoginseng $\mathrm{MeOH}$ extract on LPS-stimulated inflammation in RAW264.7 cells through the measurement of accumulated nitrite.

on NO production using LPS-stimulated RAW264.7 cells. The $n$-hexane and $\mathrm{CH}_{2} \mathrm{Cl}_{2}$ fractions significantly inhibited LPS-induced NO production at $\mathrm{IC}_{50}$ values of $1.16 \pm 0.02$ and $6.74 \pm 0.16 \mu \mathrm{g} / \mathrm{mL}$, respectively. The EtOAc fraction slightly inhibited LPS-induced NO production at a concentration of $200 \mu \mathrm{g} / \mathrm{mL}$ (Fig. 2C). As shown in Fig. 3, the $n$-hexane and $\mathrm{CH}_{2} \mathrm{Cl}_{2}$ fractions exhibited cytotoxicity from concentrations of 5 and $25 \mu \mathrm{g} / \mathrm{mL}$, respectively. Based on the aforementioned evidence, the $n$-hexane fraction strongly inhibited NO production; however, the $n$-hexane fraction also strongly damaged the RAW264.7 cells. Thus, the other active fractions, $\mathrm{CH}_{2} \mathrm{Cl}_{2}$ and EtOAc fractions, were investigated for anti-inflammatory constituents that could inhibit NO production.

In our efforts to characterize the compounds responsible for the anti-inflammatory effects, chemical investigation of $P$. notoginseng using efficient separation techniques led to the isolation of eleven compounds $(\mathbf{1}-\mathbf{1 1})$, which were identified as panaxynol (1) ${ }^{17}$ panaxydol (2), ${ }^{17}$ daucosterol (3), ${ }^{18}$ ginsenoside $\mathrm{Rh}_{1}$ (4), ${ }^{19}$ ginsenoside $\mathrm{F}_{1}(\mathbf{5}),{ }^{20}$ 6'- $O$ - 

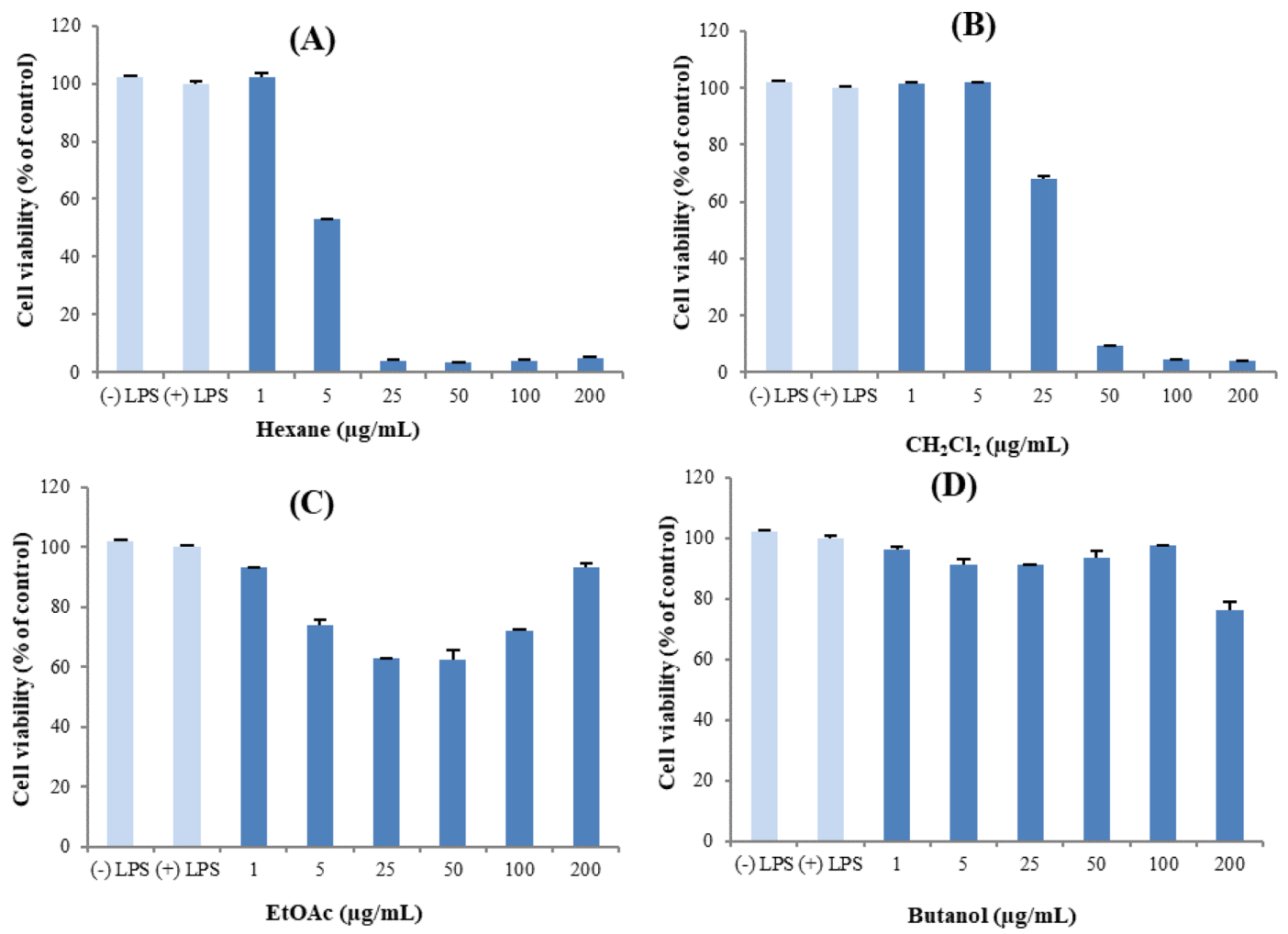

Fig. 3. The cytotoxic effects of the solvent-fractions from P. notoginseng MeOH extract on LPS-stimulated inflammation in RAW264.7 cells.
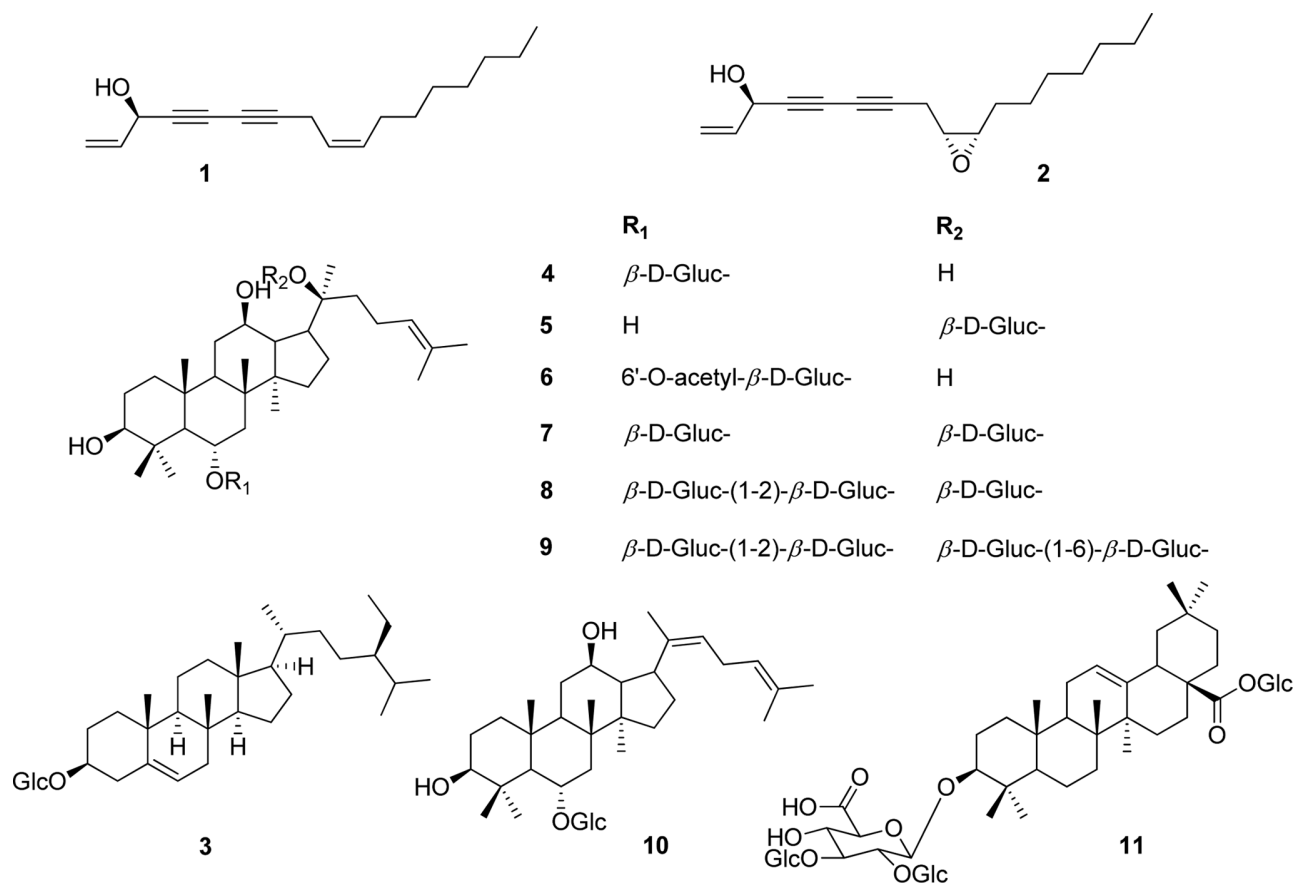

Fig. 4. Chemical structures of isolated compounds $(\mathbf{1}-\mathbf{1 1})$ from $P$. notoginseng.

acetyl ginsenoside $\mathrm{Rh}_{1}(\mathbf{6}),{ }^{21}$ ginsenoside $\mathrm{Rg}_{1}(7),{ }^{19}$ ginsenoside $\mathrm{Rd}(\mathbf{8}),{ }^{22}$ ginsenoside $\mathrm{Rb}_{1}(\mathbf{9}){ }^{7}$ ginsenoside $\mathrm{Rh}_{4}$
(10), ${ }^{23}$ and elatoside C (11). ${ }^{24}$ (Fig. 4) Among them, compound 11 was isolated from $P$. notoginseng for the first time. 
Table 1. The inhibition of isolated compounds $(\mathbf{1}-\mathbf{1 1})$ on NO production in RAW264.7 cells

\begin{tabular}{cccc}
\hline \hline Compds & $\mathrm{IC}_{50}, \mu \mathrm{M}$ & Compds & $\mathrm{IC}_{50}, \mu \mathrm{M}$ \\
\hline $\mathbf{1}$ & $>100$ & $\mathbf{7}$ & $>100$ \\
$\mathbf{2}$ & $2.28 \pm 0.15$ & $\mathbf{8}$ & $>100$ \\
$\mathbf{3}$ & $>100$ & $\mathbf{9}$ & $>100$ \\
$\mathbf{4}$ & $>100$ & $\mathbf{1 0}$ & $>100$ \\
$\mathbf{5}$ & $>100$ & $\mathbf{1 1}$ & $>100$ \\
$\mathbf{6}$ & $>100$ & Celastrol $^{\mathrm{a}}$ & $1.00 \pm 0.10$ \\
\hline
\end{tabular}

${ }^{a}$ Used as the positive control.

The eleven isolated compounds $(\mathbf{1}-\mathbf{1 1})$ were evaluated for anti-inflammatory effects on LPS-induced production of NO in RAW264.7 cells. Celastrol was used as a positive control compound with an $\mathrm{IC}_{50}$ value of $1.00 \pm$ $0.10 \mu \mathrm{M}^{25}$ According to the results shown in Table 1, only compound 2 , panaxydol, displayed a highly potent inhibition of $\mathrm{NO}$ production with an $\mathrm{IC}_{50}$ value of $2.28 \pm$ $0.15 \mu \mathrm{M}$, whereas the other compounds did not show inhibitory activities in this cell system.

Interleukin-2 (IL-2) is a 15000 dalton glycoprotein that allows the in vitro expansion of antigen- or lectin-activated cells. This is mediated by an endogenous hormone-like control system with highly specific receptors. ${ }^{26}$ Although the IL-2 is stable in blood in vitro, ${ }^{27}$ it disappears with a half-life of between 3 and $5 \mathrm{~min}$ from the circulation of humans and mice. ${ }^{28,29}$ This is consistent with its role as a transient signal in immune responses, it might therefore be expected that transcription of IL-2 mRNA should occur only as long as the Th lymphocyte is in contact with the stimulating agent, and that it should be short lived, so that it disappears soon after the antigenic stimulus is removed. IL-2 mRNA is not synthesized constitutively in $\mathrm{T}$ lymphocytes, but only after stimulation with $\mathrm{T}$ cell activators. $^{30}$

Simultaneously with the examination of anti-inflammatory properties, the $\mathrm{MeOH}$ extract of $P$. notoginseng was also examined for immunosuppressive properties by evaluating IL-2 mRNA expression in a dose-dependent manner. The treatment of Jurkat $\mathrm{T}$ cells with phorbol 12myristate 13-acetate (PMA)/A23187 strongly induced IL2 mRNA expression. IL-2 levels were significantly decreased after treatment with $P$. notoginseng $\mathrm{MeOH}$ extract at a concentration at $400 \mu \mathrm{g} / \mathrm{mL}$ (Fig. 5). Therefore, the $P$. notoginseng $\mathrm{MeOH}$ extract might exert inhibitory effects on IL-2 expression.

In support of the inhibitory effects on IL-2 expression by $P$. notoginseng, four main fractions, $n$-hexane, $\mathrm{CH}_{2} \mathrm{Cl}_{2}$, EtOAc, and $n$-butanol, were used for the treatment of Jurkat T cells stimulated with PMA/A23187 at a con-

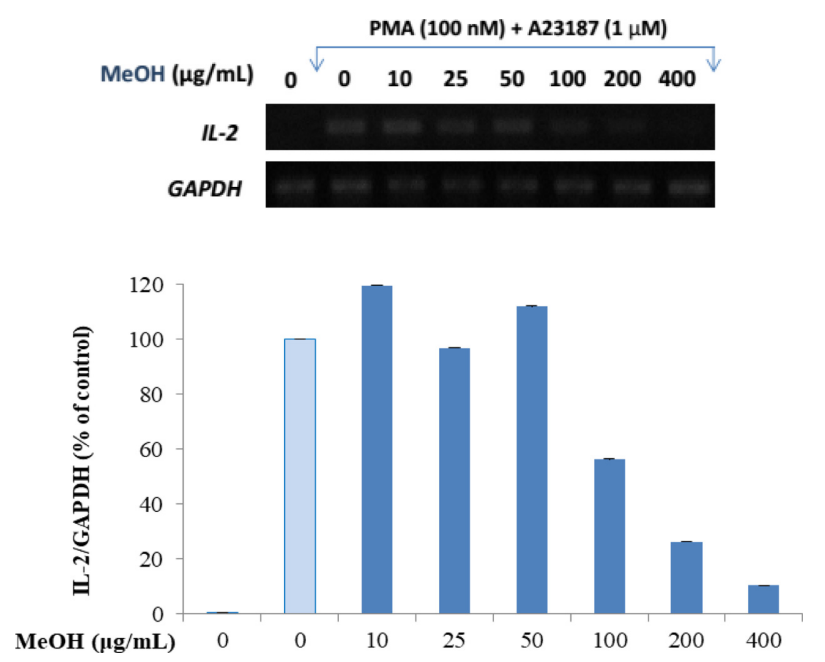

Fig. 5. The inhibition of $P$. notoginseng $\mathrm{MeOH}$ extract on IL-2 production in activated T cells. Jurkat T cells $\left(1 \times 10^{6}\right.$ cells/well $)$ were pre-incubated for $30 \mathrm{~min}$ with $\mathrm{MeOH}$ extract at a dosedependent manner, and then the cells were stimulated for $6 \mathrm{~h}$ with PMA $(100 \mathrm{nM}) / \mathrm{A} 23187(1 \mu \mathrm{M})$. After $6 \mathrm{~h}$, IL-2 mRNA levels were detected by PCR. Image $\mathrm{J}$ software was used to demonstrate graph for quantification.

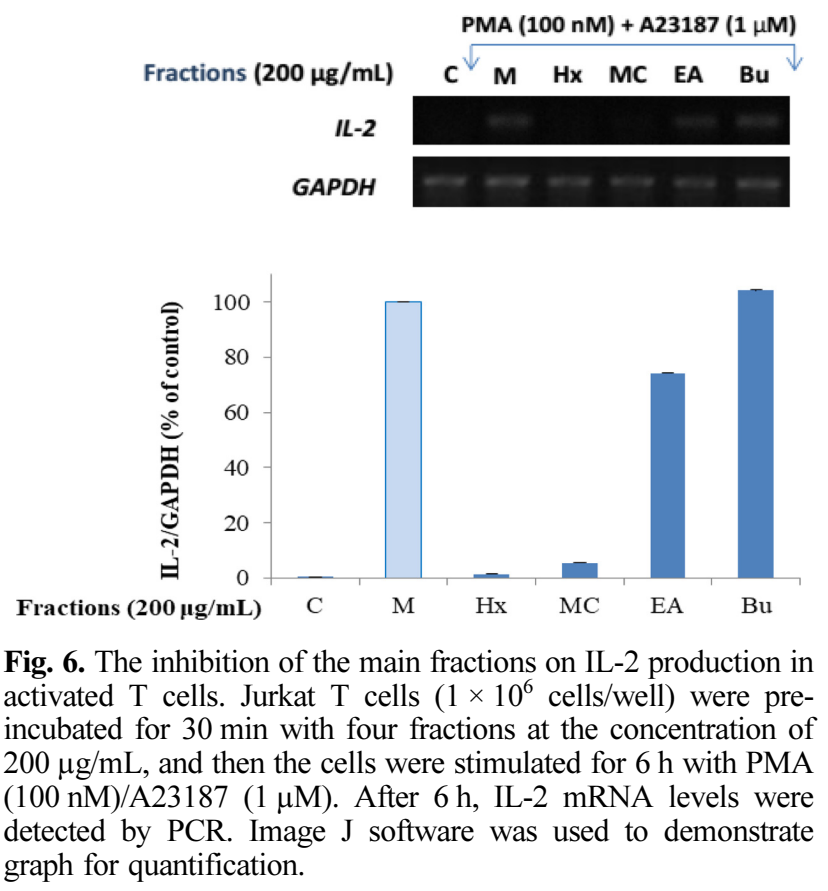

centration of $200 \mu \mathrm{g} / \mathrm{mL}$. As shown in Fig. 6, the $n$ hexane and $\mathrm{CH}_{2} \mathrm{Cl}_{2}$ fractions significantly abolished IL-2 mRNA expression, whereas the other fractions did not inhibit IL-2 expression. Thus, the $n$-hexane and $\mathrm{CH}_{2} \mathrm{Cl}_{2}$ fractions were subsequently used to treat Jurkat $\mathrm{T}$ cells stimulated with PMA/A23187 at various concentrations. The results revealed that the $n$-hexane and $\mathrm{CH}_{2} \mathrm{Cl}_{2}$ fractions potently regulated IL-2 mRNA expression at 

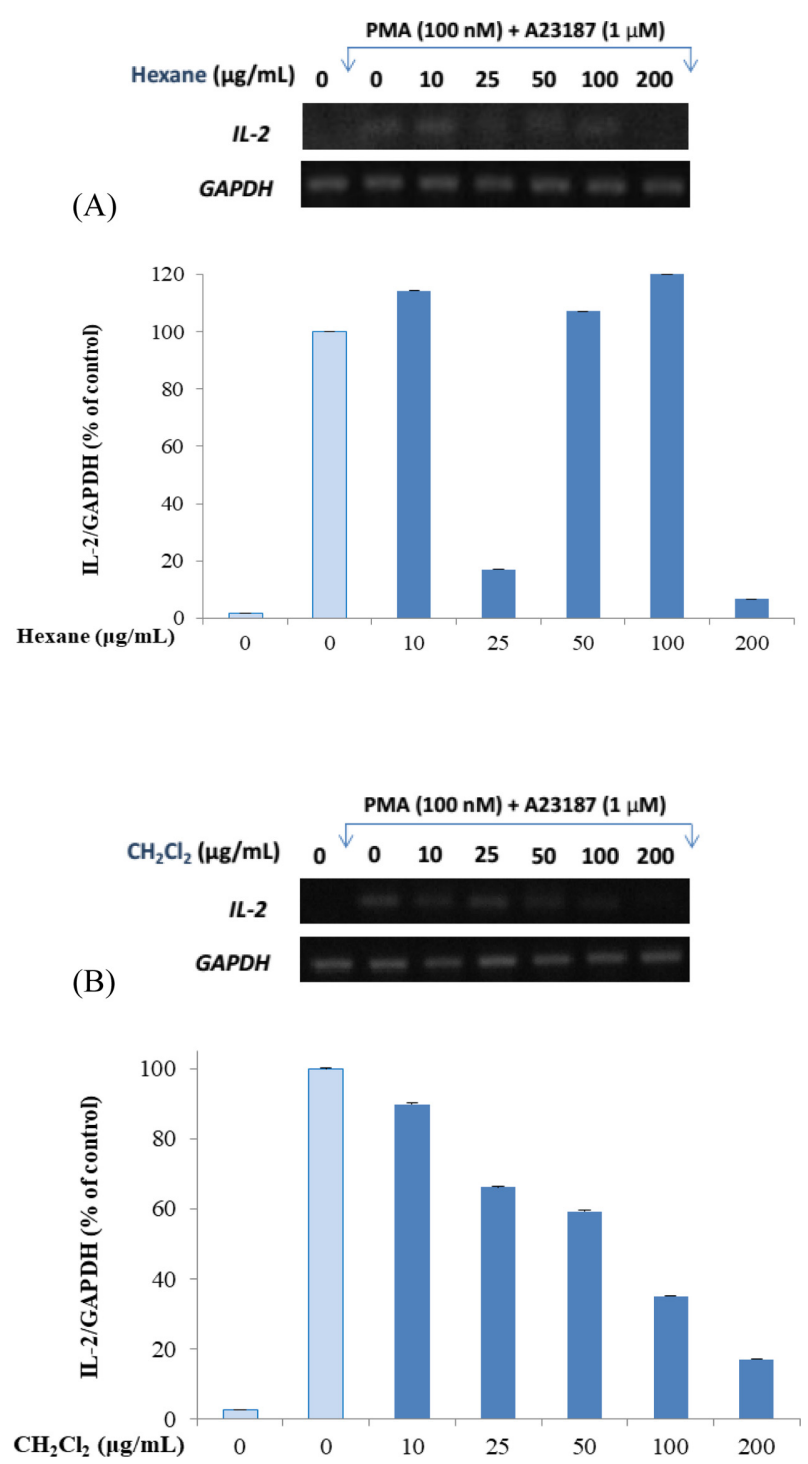

Fig. 7. The inhibition of $n$-hexane and $\mathrm{CH}_{2} \mathrm{Cl}_{2}$ fractions on IL-2 production in activated $\mathrm{T}$ cells. Jurkat T cells $\left(1 \times 10^{6}\right.$ cells/well $)$ were pre-incubated for $30 \mathrm{~min}$ with four fractions at the various concentrations, and then the cells were stimulated for $6 \mathrm{~h}$ with PMA $(100 \mathrm{nM}) / \mathrm{A} 23187(1 \mu \mathrm{M})$. After $6 \mathrm{~h}$, IL-2 mRNA levels were detected by PCR. Image J software was used to demonstrate graph for quantification.

concentrations of $200 \mu \mathrm{g} / \mathrm{mL}$ (Fig. 7).

To determine which compounds showed inhibitory effects on $\mathrm{T}$ cell activation, the eleven isolated compounds $(\mathbf{1}-\mathbf{1 1})$ were screened by evaluating IL-2 mRNA expression in Jurkat $\mathrm{T}$ cells stimulated with PMA/ A23187. Among the isolated compounds, panaxydol (2) exhibited potent inhibition of IL-2 expression in activated Jurkat $\mathrm{T}$ cells at a concentration of $100 \mu \mathrm{M}$, whereas the other isolated compounds did not inhibit the expression (Fig. 8). Hence, panaxydol (2) might inhibit IL-2 expression.

Then, to confirm whether panaxydol (2) regulated $\mathrm{T}$

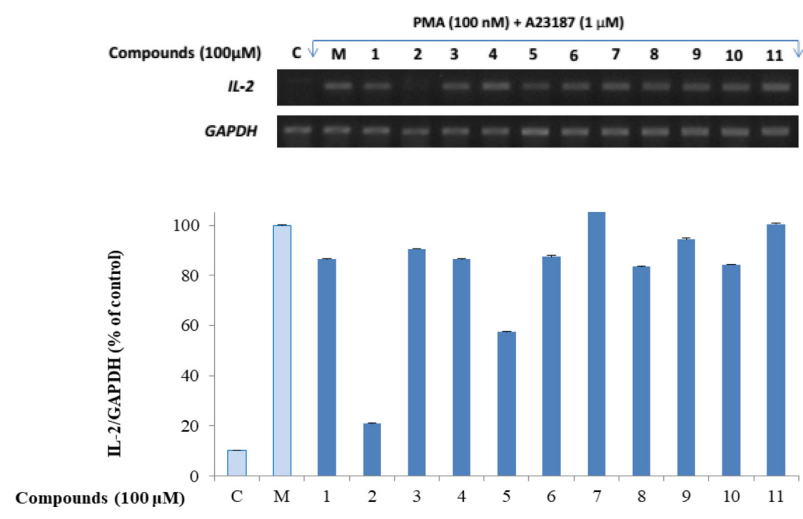

Fig. 8. The inhibition of isolated compounds on IL-2 production in activated $\mathrm{T}$ cells. Jurkat $\mathrm{T}$ cells $\left(1 \times 10^{6}\right.$ cells/well $)$ were preincubated for $30 \mathrm{~min}$ with four fractions at the concentration of $100 \mu \mathrm{M}$, and then the cells were stimulated for $6 \mathrm{~h}$ with PMA $(100 \mathrm{nM}) / \mathrm{A} 23187(1 \mu \mathrm{M})$. After $6 \mathrm{~h}$, IL-2 mRNA levels were detected by PCR. Image $J$ software was used to demonstrate graph for quantification.
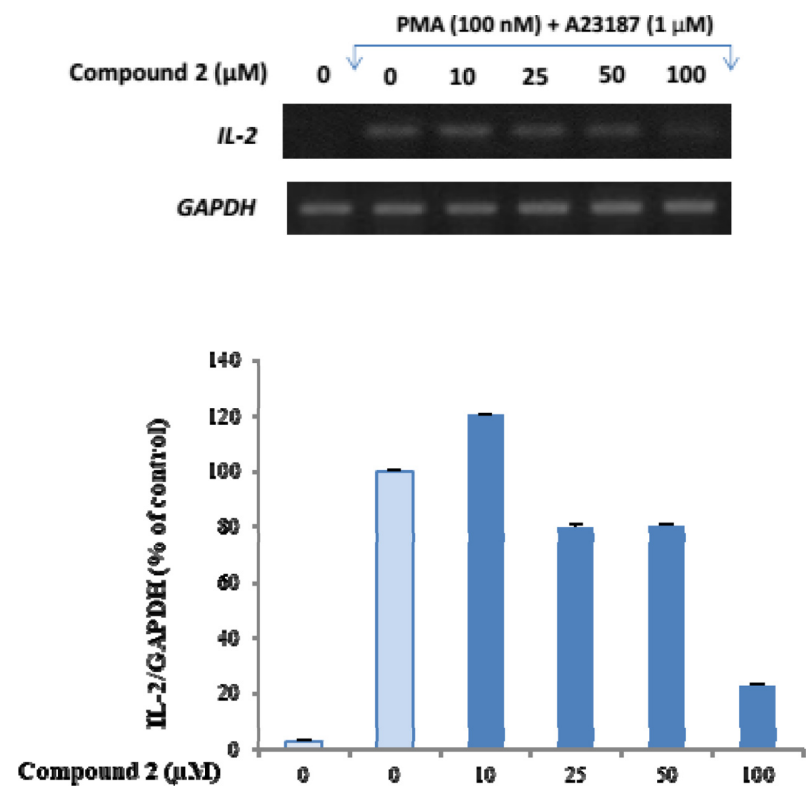

Fig. 9. Compound 2 inhibits IL-2 production in activated T cells. Jurkat $\mathrm{T}$ cells $\left(1 \times 10^{6}\right.$ cells/well $)$ were pre-incubated for $30 \mathrm{~min}$ with or without indicated concentrations of $2(0-100 \mu \mathrm{M})$, and then the cells were stimulated for $6 \mathrm{~h}$ with PMA $(100 \mathrm{nM}) /$ A23187 $(1 \mu \mathrm{M})$. After $6 \mathrm{~h}$, IL-2 mRNA levels were detected by PCR. Image $\mathbf{J}$ software was used to demonstrate graph for quantification.

cells activities, cells were pre-incubated with panaxydol (2) at various concentrations for $30 \mathrm{~min}$ before treatment with PMA/A23187. After $6 \mathrm{~h}$, the IL-2 mRNA levels were measured by PCR. Panaxydol (2) down-regulated the expression of IL-2 mRNA in Jurkat $\mathrm{T}$ cells in a concentration-dependent manner (Fig. 9). The results revealed that panaxydol (2) inhibited IL-2 transcription 
and secretion in PMA/A23187-stimulated Jurkat T cells in a concentration-dependent manner with an $\mathrm{IC}_{50}$ value of $65.57 \pm 0.49 \mu \mathrm{M}$.

Panaxydol (2), a polyacetylenic compound, displayed a significant inhibitory effect on NO synthesis and a slight immunosuppressive effect, while the other isolated compounds, saponins, showed no anti-inflammatory or immunosuppressive activities. The above-mentioned data showed that the polyacetylene derivatives had the most potent anti-inflammatory and immunosuppressive effects. ${ }^{31}$ Triple bond functionality of polyacetylenes transforms these natural products to a very interesting group of compounds whose reactivity towards proteins and other biomolecules may explain their wide variety of bioactivities. Polyacetylenes isolated from the botanically related plant families Apiacea, Asteraceae, and Araliaceae have been reported to possess various biological activities, including anti-inflammation, anti-cancer, and anti-oxidant as well as immunosuppressive effect. ${ }^{31-35}$ Moreover, compound $\mathbf{1}$ is also a polyacetylenic compound but it did not affect the production of NO or the expression of IL-2. Compound $\mathbf{2}$ differs from compound $\mathbf{1}$ by an epoxide functional group at the position of $\mathrm{C}_{9}-\mathrm{C}_{10}$. This suggests that the presence of an epoxide functional group might increase the anti-inflammatory effect and improve the immunosuppressive effect.

In the current study, we found that the $\mathrm{MeOH}$ extract of $P$. notoginseng roots inhibited NO production in LPSactivated RAW264.7 macrophages. Also, the $P$. notoginseng $\mathrm{MeOH}$ extract displayed immunosuppressive effects on Jurkat $\mathrm{T}$ cells. The phytochemical investigation of $P$. notoginseng led to the isolation of eleven compounds (1 11). Compound 2, panaxydol, showed the most potent inhibition of NO production and potent inhibition of IL-2 expression with $\mathrm{IC}_{50}$ values of $2.28 \pm 0.15$ and $65.57 \pm$ $0.49 \mu \mathrm{M}$, respectively. These findings provide experimental evidence that panaxydol (2) could contribute to the health benefits of $P$. notoginseng as an anti-inflammatory agent, as well as an immunosuppressive agent.

\section{Acknowledgements}

This study was supported by the research grant from Daegu Catholic University in 2019 (Grant No. DCU20191034).

\section{Conflict of interest}

The authors declare no conflict of interest.

\section{References}

(1) Medzhitov, R.; Janeway, C. A. Jr. Curr. Opin. Immunol. 1997, 9, 4-9. (2) Yang, Z.; Matteson, E. L.; Goronzy, J. J.; Weyand, C. M. Arthritis. Res. Ther. 2015, 17, 29.

(3) Yu, T. K.; Caudell, E. G.; Smid, C.; Grimm, E. A. J. Immunol. 2000, 164, 6244-6251.

(4) Medzhitov, R.; Janeway, C. A. Jr. Science 2002, 296, 298-300.

(5) Xu, W.; Larbi, A. Exp. Gerontol. 2018, 107, 98-101.

(6) Wang, C. Z.; McEntee, E.; Wicks, S.; Wu, J. A.; Yuan, C. S. J. Nat. Med. 2006, 60, 97-106.

(7) Lee, D. G.; Lee, J.; Yang, S.; Kim, K. T.; Lee, S. Nat. Prod. Sci. 2015, 21, 111-121.

(8) Lau, A. J.; Woo, S. O.; Koh, H. L. J. Chromatogr. A. 2003, 1011, 7787.

(9) Ng, T. B. J. Pharm. Pharmacol. 2006, 58, 1007-1019.

(10) Li, S. H.; Chu, Y. Acta Pharmacol. Sin. 1999, 20, 551-554.

(11) Zhao, G. R.; Xiang, Z. J.; Ye, T. X.; Yuan, Y. J.; Guo, Z. X. Food Chem. 2006, 99, 767-774.

(12) Ahn, K. S.; Noh, E. J.; Zhao, H. L.; Jung, S. H.; Kang, S. S.; Kim, Y. S. Life Sci. 2005, 76, 2315-2328.

(13) El-Desouky, S. K.; Gamal-Eldeen, A. M. Pharm. Biol. 2009, 47, 872-877.

(14) Kim, D. C.; Ko, W.; Ha, T. M..; Nhiem, N. X.; Yen, P. H.; Tai, B. H.; Truong, L. H.; Long, V. N.; Gioi, T.; Hong Quang, T.; Minh, C. V.; Oh, H.; Kim, Y. C.; Kiem PV. Pharm. Biol. 2017, 55, 1195-1201.

(15) Min, B. S.; Cuong, T. D. Nat. Prod. Sci. 2013, 19, 201-205.

(16) Cao, T. Q.; Tran, M. H.; Kim, J. A.; Tran, P. T.; Lee, J. H.; Woo, M. H.; Lee, H. K.; Min, B. S. Bioorg. Med. Chem. Lett. 2015, 25, 50875091.

(17) Knispel, N.; Ostrozhenkova, E.; Schramek, N.; Huber, C.; PeñaRodríguez, L. M.; Bonfill, M.; Palazón, J.; Wischmann, G.; Cusidó, R. M.; Eisenreich, W. Molecules 2013, 18, 7686-7698.

(18) Lee, J. M.; Lee, D. G.; Lee, K. H.; Cho, S. H.; Nam, K. W.; Lee, S. H. Afr. J. Pharm. Pharmacol. 2013, 7, 294-301.

(19) Han, M.; Hou, J. G.; Dong, C. M.; Li, W.; Yu, H. L.; Zheng, Y. N.; Chen, L. Molecules. 2010, 15, 399-406.

(20) Ko, S. R.; Choi, K. J.; Suzuki, K.; Suzuki, Y. Chem. Pharm. Bull. 2003, 51, 404-408.

(21) Yu, H. S.; Zhang, L. J.; Song, X. B.; Liu, Y. X.; Zhang, J.; Cao, M.; Kang, L. P.; Kang, T. G.; Ma, B. P. China J. Chin. Mater. Med. 2013, 38, 3910-3917.

(22) Cho, J. G.; Lee, M. K.; Lee, J. W.; Park, H. J.; Lee, D. Y.; Lee, Y. H.; Yang, D. C.; Baek, N. I. J. Ginseng Res. 2010, 34, 113-121.

(23) Yang, H. J.; Kim, J. Y.; Kim, S. O.; Yoo, Y. H.; Sung, S. H. J. Ginseng Res. 2014, 38, 194-202.

(24) Yoshikawa, M.; Matsuda, H.; Harada, E.; Murakami, T.; Wariishi, N.; Yamahara, J.; Murakami, N. Chem. Pharm. Bull. 1994, 42, 13541356.

(25) Ngo, Q. T.; Cao, T. Q.; Tran, P. L.; Kim, J. A.; Seo, S. T.; Kim, J. C.; Woo, M. H.; Lee, J. H.; Min, B. S. Bioorg. Med. Chem. Lett. 2018, 28 , 2109-2115.

(26) Robb, R. J.; Munck, A.; Smith, K. A. J. Exp. Med. 1981, 154, 1455-1474.

(27) Hooton, J. W.; Gibbs, C.; Paetkau, V. J. Immunol. 1985, 135, 24642473.

(28) Muhlradt, P. F.; Opitz, H. G. Eur. J. Immunol. 1982, 12, 983-985.

(29) Lotze, M. T.; Frana, L. W.; Sharrow, S. O.; Robb, R. J.; Rosenberg, S. A. J. Immunol. 1985, 134, 157-166.

(30) Shaw, J.; Meerovitch, K.; Bleackley, R. C.; Paetkau, V. J. Immunol. 1988, 140, 2243-2248.

(31) Pereira, R. L.; Ibrahim, T.; Lucchetti, L.; da Silva, A. J.; Goncalves de Moraes, V. L. Immunopharmacology 1999, 43, 31-37. 
(32) Jin, L.; Zhou, W.; Li, R.; Jin, M.; Jin, C.; Sun, J.; Li, G. Nat. Prod. Res. 2019, 1-4.

(33) Christensen, L. P. Recent Pat. Food Nutr. Agric. 2011, 3, 64-77.

(34) Chien, S. C.; Tseng, Y. H.; Hsu, W. N.; Chu, F. H.; Chang, S. T.; Kuo, Y. H.; Wang, S. Y. Nat. Prod. Commun. 2014, 9, 1589-1590.

(35) Shim, S. Y.; Sung, S. H.; Lee, M. Pharmacogn. Mag. 2018, 14 , 358-362.

Received May 30, 2019 Revised September 10, 2019 Accepted September 18, 2019 